\section{SUMMARY REPORTS}

Consultation I: Latin America with special reference to foreign investment in Chile during Allende administration

Consultation II: Asia and the Pacific with special reference to foreign investment in the Philippines and India

Consultation III: Disclosure. Transfer Pricing and Employee Relations by Jack Blum. Associate Coun sel. U.S. Senate Committee on Multinational Corporations

Consultation IV: A Code of Ethics: The Structure of the Question; a task force committee report representing corporations. developing countries. U.S government and religious organizations

Consultation V: Report of the Rapporteur. Working Group I: Tax Deferral. Access to Raw Materials. New International Regimes

Report of the Rapporteur. Working Group II: The Transnational Corporation and Ten Principles of the New International Economic Order

A New U.S. Policy Towards Foreign Direct Investment. C. Fred Bergsten $\$ 1.00$ each

Order from

COUNCIL ON RELIGION \& INTERNATIONAL AFFAIRS (CRIA) 170 E. 64th Street. New York N Y 10021
SPECIAL STUDIES

The Nation State and the Transnational Corpora. tion with Special Reference to Latin America

This 242 page study analyzes the case study of Dow Chemical in Chile along with the issues of disclosure legal limitations of transnational corporations ac. tivities and international regulation of transnational corporations

Edited by Jon P. Gunnemann 242 pages/\$3 50/paper

The Multinational Corporation and Social Policy: General Motors in South Africa

An examination of General Motors employment policy in South Africa.

Edited by Richard A. Jackson 113 pages/\$2 95/paper

People/Profits: The Ethics of Investment

Investor Responsibility for the foreign affairs of trans national corporations.

Edited by Charles A. Powers 214 pages/\$2 95/paper

\section{TASK.FORCE STATEMENTS}

Value Systems and the World Food Crisis with special reference to the transnational corporation The agenda of action for Carnegie Center for Transna. tional Studies task force. $\$ 100$
Deir Yassin:

\section{Myth and Fact}

To the Editors: It pains me that such an intelligent and interesting magazine as Worldview should be guilty of propagating an untrue story. Unfortunately, such is apparently the case. In the article "One Answer to Terrorism" (May) Lawrence Shook comments, in describing government terrorism around the world, "Even the Israelis are guilty: Deir Yassin, 1948, where two hundred Arab men, women, and children were massacred," Deir Yassin is constantly held up as an example of Israeli wanton brutality, but it's just not true.

The Deir Yassin incident is explained fully in Myths and Facts 1976, published by Near East Report of Washington, D.C. The publication explains that an authoritative study about Deir Yassin was published in 1969 by the Israeli Minister for Foreign Affairs. Here are some relevant excerpts from Myths and Facts 1976 on Deir Yassin:

"On April 10, 1948, about 100 members of the Jewish Irgun and Stern groups drove up to the village... and ordered it to surrender. Over 200 Arabs evacuated the village immediately and were escorted by the Irgun, unharmed, back to Jerusalem.

"White flags were extended from the windows of the buildings nearest the Jewish forces. An advance party entered the village and was hit by a hail of bullets.

"Fierce house-to-house fighting followed....

"When the attack ended, it was found that 254 civilians had been killed. They had either been held as hostages by the Iraqi and Palestinian army regulars who ambushed the Irgun or they had sought protection with the Arab soldiers.

"Yunes Ahmad Assad, a prominent Arab survivor of Deir Yassin, said: 'The Jews never intended to hurt the population of the village, but were forced to do so after they met enemy fire which killed the Irgun commander.' (Al Urdan, Apr. 9, 1955)"

Montreal, P.Q., Canada

David E. Pinto

Lawrence Shook Responds:

Re: David E. Pinto's thoughtful letter regarding the Deir Yassin reference in the "One Answer to Terrorism"' story. I am honored by his intelligent response

$\mathrm{Mr}$. Pinto regards the tragedy at Deir Yassin as popularly misconstrued. Maybe it is. If so, I am indeed guilty of furthering a misunderstanding; I had no primary sources concerning the incident

Nevertheless, I'm afraid my reply to Mr. Pinto's letter cannot be very sooth. ing to him. My research folder on the killing of Leland Phelps weighs about four pounds and contains two dozen sources on the subject of international terrorism. Because Deir Yassin is so frequently cited as one example of terrorism by a wide range of sources, 1 reported it as such. Among a host of other references to the incident contained in my research is a January, 1973, Current Affairs article that calls Deir Yassin terrorism

Contravening that assertion. Mr. Pinto adduces a study published by the Israeli Minister for Foreign Affairs. I can only say that as a reporter, 1 could not regard that single source as a completely objective or conclusive one. No more than I could accept the U.S. Army's initial self-investigation of its performance at Mylai. 